\title{
Genetic Variability Study of Rice Germplasm Accessions under Aerobic Condition
}

\author{
M. S. Sowjanya*, H. V. Vijayakumar Swamy, H. E. Shashidhar, \\ Prakash Patil and H. S. Vimarsh \\ Department of Plant Biotechnology, UAS, GKVK, Bangalore, India \\ *Corresponding author
}

\section{A B S T R A C T}

\begin{tabular}{|l|}
\hline Ke y w o r d s \\
$\begin{array}{l}\text { Aerobic condition, } \\
\text { Rice, Genetic } \\
\text { Variability }\end{array}$ \\
\hline Article Info \\
$\begin{array}{l}\text { Accepted: } \\
\text { 04 December } 2020 \\
\text { Available Online: } \\
\text { 10 January } 2021\end{array}$ \\
\hline
\end{tabular}

Potential challenge to rice is water scarcity. Water saved in rice cultivation, will help increase cultivable areas of rice and cultivation of other crops. Aerobic cultivation is one of such systems where rice is cultivated under arid conditions with minimal water. Seventy-four rice genotypes were studied under aerobic condition manifested high GCV, PCV and narrow differences in PCV and GCV for test weight, days to fifty percent flowering, plant height, grain yield per plant, plant height, panicle length, decorticated grain length\& width, number of tillers, number of productive tillers, grain width. This suggested the presence of negligible influence of external factors for those traits. Present study revealed highest heritability with genetic advance as per cent means for all the traits including yield $(72.28 \%, 57.82)$ except grain length \& flag leaf length indicating the presence of considerable variation and additive gene effects. Hence, improvement of these characters could be effective through phenotypic selection under aerobic condition. Better performing lines from the study would be the better source for developing drought tolerant rice also saline tolerant rice under aerobic condition.

\section{Introduction}

Rice, the important staple food crop of the world feeds over half global population. Rice producing people of Asian continent are getting a major proportion of required energy from rice crop and the rice demand is expected to increase by $38 \%$ within 30 years.

However, the rate of increase of rice production is slowing down and if the trend is not reversed, severe food shortages will occur in near future. To meet the food demand, it is necessary to increase rice production either by increasing the yield per unit area or by increasing the cultivated areas (Ray and Islam, 2008). Rice is also among the crops that consume large share of irrigation water. Water saved in rice cultivation, will help increase cultivable areas and cultivation of other crops.

Aerobic condition is one of such systems where rice is cultivated under arid conditions with minimal water without transplanting and puddling, potentially reducing most of the 
pest and disease incidence. As the cultivating conditions changes, there will be changes in the soil microenvironment, $\mathrm{pH}$, composition etc. Recent findings also suggest a greater number of beneficial micro-organisms dwell in aerobic condition (Shashidhar, 2007).

Drought is the first most widespread soil problem in rice growing countries which considers as a serious constraint to increased rice production worldwide. The cost effective and easiest way of addressing drought and also salinity is by development of a drought tolerant variety. For varietal development, the first important step is to screen the existing rice germplasms to identify breeding materials. Landraces are currently exploited as potential donors of drought and salinity traits due to their adaptation to local conditions (Roy et al., 2011).

Aerobic rice has one of the challenges of salinity issue, as chances of salts coming in contact with the rhizosphere increases because of less moisture content in the soil. Salts which would have accumulated across so many years will come up due to capillary force and pose threat to the crop plant under aerobic condition. Addressing this challenge of salinity in case of aerobic rice stays unattended and needs to be addressed by keeping the future scope of the aerobic cultivation.

Enhancing abiotic stress tolerance in crop plants, it is very important to find sufficient variation and to devise such screening techniques which are reliable to identify tolerant genotypes. Variation for abiotic stress tolerance has been reported in many crop species, both between and within plant species of rice (Alam et al., 2004) and other crop plants.

Keeping these points in view, present study was conducted to see the variation among the genotypes under aerobic condition, for development of drought and salinity tolerant variety.

\section{Materials and Methods}

The experiment was carried out during Kharif seasons of 2016 at Department of Plant Biotechnology, University of Agricultural Sciences, GKVK campus, Bangalore, India located at the latitude of $12^{\circ} 58^{\prime}$ North; longitude $77^{\circ} 35^{\prime}$ East and altitude of 930 meters above mean sea level (MSL).

Total 74 germplasms lines (including five checks) were studied using Augmented RCBD design with the spacing of $30 \times 10 \mathrm{~cm}$ under aerobic condition. List of the genotypes used in the present study are given in the Table 1. Five checks namely ARB-6, AM143, Pokkali L, IR-64 and Chittimuthyalu were used. Sowing was done in Augmented RCBD design, with 10 blocks comprising of 7 germplasm lines and five checks repeated in each block.

Three plants from all genotypes were used for recording observation and mean values ofthe traits were used for statistical analysis. The characters observed for eliciting the information under field are days to fifty percent flowering, plant height at maturity, total number of tillers, number of productive tillers at maturity, panicle length, flag leaf length, grain length, grain width, decorticated grain length and width, biomass, grain yield per plant and test weight.

\section{Statistical analysis}

The mean values of three plants used for recording the observations were analysed using R statistical package.

Estimation of genetic variability parameters like Phenotypic and Genotypic coefficient of 
variation (PCV and GCV) were done using formula given by Burton and Dewane (1953) for low moisture stress. PCV and GCV with 0-10 per cent was considered as low, 10-20 per cent as moderate and 20 per cent and above as high.

Broad sense Heritability $\left(\mathrm{h}^{2}\right)$ estimate as per cent mean was calculated using the formula given by Hanson et al., 1956 where, 0-30 per cent was considered as low, 30-60 per cent was considered as moderate and 60 per cent and above as high. Genetic advance and Genetic Advance means (GAM) were also calculated where $0-10$ per cent was considered as Low, 10-20 per cent as moderate and 20 per cent and above as high.

\section{Results and Discussion}

\section{Analysis of variance}

Highly significant differences were observed for all the yield attributing traits indicating presence of sufficient amount of variability among the genotypes studied (Table 2). The accessions are the diverse germplasms which serve as a good source of variability, resulted many better yielding germplasm lines under Aerobic condition. Better performing accessions would be the better source for studying salinity and drought under aerobic condition.

\section{Mean performance of genotypes}

The mean value in 74 rice genotypes for 12 characters (Table 3) are briefly described below. The range of variation for days to 50 per cent flowering was 82 days to 119 days with an average value of 98.92 days. Plant height was varied from $43.32 \mathrm{~cm}$ to $133.65 \mathrm{~cm}$ with an average of $75.36 \mathrm{~cm}$. The variation for number of tillers per plant was ranging from7.92 to 36.82 with an average value of 23.88. Variation for number of tillers per plant was from 5.63 to 31.23 with an average value of 19.24. Flag leaf length was ranged from $12.45 \mathrm{~cm}$ to $33.43 \mathrm{~cm}$ with an average value of $20.25 \mathrm{~cm}$. Panicle length was fluctuated from $9.34 \mathrm{~cm}$ to $25.01 \mathrm{~cm}$ with an average value of $16.92 \mathrm{~cm}$. Test weight was ranged from $9.59 \mathrm{~g}$ to $28.66 \mathrm{~g}$ with an average value of $18.73 \mathrm{~g}$.

Highest grain length was $11.1 \mathrm{~mm}$, and the lowest was $5.80 \mathrm{~mm}$ with an average of 7.54 $\mathrm{mm}$. Grain width range was from $1.51-3.32$ mm with a mean of $2.54 \mathrm{~mm} .1 .54 \mathrm{~mm}$ to $8.08 \mathrm{~mm}$ was the range of variation for decorticated grain length and the mean was $4.66 \mathrm{~mm}$. After decorticating the grain, the shortest width was $1.43 \mathrm{~mm}$, and the highest was $2.72 \mathrm{~mm}$ with an average of $2.15 \mathrm{~mm}$ was observed. The variation range for grain yield per plant was from $0.11 \mathrm{~g}$ to $6.01 \mathrm{~g}$ with an average value of $2.55 \mathrm{~g}$.

The mean performance of seventy- four genotypes used in the present study indicated that no single rice genotype was superior for all the traits studied. Highly significant differences among the genotypes were observed for all the observations representing presence of diversity among the seventy-four genotypes studied.

The analysis of variance data manifested highly significant variance (at $0.1 \%$ ) due to treatment (genotype is considered as treatment), showing inherent genetic difference among the genotypes. Significant genetic variation in various component characters exhibited by these genotypes indicated the efficiency of selection these characters.

Variability, heritability and genetic advance

The existence of genetic variability and heritability highly influences the 
improvement of a plant trait. In any breeding program, prior knowledge on the estimates of variability in the population and heritable components of the trait are useful tools. Attempts to improve a character by selection would be more difficult unless a major portion of the variation is heritable.

Thus, information on both phenotypic and genotypic coefficient of variation and heritability of the character would be advantageous to breeding. Hence, the coefficient of variation expressed at phenotypic and genotypic levels were used to compare the variability observed among different characters.

The variability parameters viz., mean, minimum, maximum, standard error, standard deviation, estimates of genotypic co-efficient of variation (GCV), phenotypic co-efficient of variation $(\mathrm{PCV})$, environmental co-efficient of variation (ECV), heritability in broad senseh $^{2}$ and genetic advance as per cent mean with respect to yield and yield attributed traits (Table 3)are briefly described below.

\section{Days to fifty per cent flowering}

Days to fifty percent flowering exhibited moderate GCV (11.18 \%) and PCV (11.67\%) and ECV (6.79 \%) along with the high heritability and high genetic advance as per cent mean of $91.72 \%$ and 22.05 respectively.

\section{Plant height}

Plant height exhibited moderate GCV (23.86 $\%)$ and PCV (24.37 \%) ECV (4.96 \%) along with the high heritability value of $84.37 \%$ and high GAM of 26.74 .

\section{Total number of tillers per plant}

Number of tillers per plant exhibited high GCV $(27.66 \%$,) and PCV (34.45 \%) and ECV
(20.52\%) along with the high heritability value of $64.50 \%$ and high GAM of 45.85.

\section{Number of productive tillers per plant}

Number of productive tillers per plant exhibited high GCV (31.02 \%), PCV $(37.16 \%)$ and ECV (20.45 \%), along with the high heritability value of $69.70 \%$ and high GAM of 53.44.

\section{Flag leaf length $(\mathrm{cm})$}

Moderate GCV, PCV and ECV value of 3.89 $\%, 20.56 \%$ and $15.15 \%$ respectively with moderate heritability and GAM of $45.68 \%$ and 19.37 was observed for this trait.

\section{Panicle length $(\mathrm{cm})$}

Moderate GCV, PCV and ECV were observed for panicle length $(15.86 \%, 17.52$ $\%$ and $7.44 \%$ ) with high $81.97 \%$ broad sense heritability and 29.62 GAM was observed.

\section{Test weight $(g)$}

The GCV PCV and ECV was high with 25.89 $\%, 26.00 \%$ and $2.39 \%$ for test weight. Heritability and GAM were very high for this trait with $99.16 \%$ and 53.18 respectively.

\section{Grain length (mm)}

Grain length had low GCV, PCV and ECV with values of $7.09 \%$, PCV of $9.87 \%$, and ECV of $6.87 \%$ also, moderate broad sense heritability was observed $(51.58 \%)$ with moderate GAM (10.51).

\section{Grain width $(\mathbf{m m})$}

Moderate GCV (13.92\%) and PCV (16.21 $\% \%)$ and $\mathrm{ECV}(8.27 \%)$ was observed for grain width with the high heritability value of $73.98 \%$ and high GAM of 24.74 . 


\section{Decorticated grain length (mm)}

High GCV, PCV and ECV was exhibited by decorticated grain length with $31.42 \%, 32.40$ $\%$ and $7.94 \%$ respectively. The heritability and genetic advance were also very high $94 \%$ and 62.83 respectively.

\section{Decorticated grain width (mm)}

Decorticated grain width had moderate GCV (12.69 \%, and PCV (15.10 \%) and ECV (8.18 $\%)$ with high heritability $(70.64 \%)$ and high GAM (22.01).

\section{Grain yield per plant (g)}

High GCV, PCV and ECV of $(32.97 \%, 38.77$ $\%$ and $20.41 \%$ respectively was observed for grain yield with the high heritability $(72.28$ $\%)$ and GAM (57.82).

Many of these traits had high GCV, PCV and ECV suggested that these traits are under the relatively greater influence of genetic factors and relatively less influence of the environment. Hence, these characters can be relied upon and simple selection can be practiced for further improvement. These results were in conformity with Bisne et al., (2009) for grain yield per plant. Similar results were also reported for number of tillers per plant and number of productive tillers per plant (Elayaraja et al., 2005) and test weight (Kumar et al., 2001). Grain length exhibited lower GCV, PCV and ECV indicated lower amount of variability for grain length.

Table.1 List of Genotypes used for the study under Aerobic condition

\begin{tabular}{|c|l|c|l|c|l|l|l|}
\hline Sl. No. & Genotypes & $\begin{array}{c}\text { Sl. } \\
\text { No }\end{array}$ & Genotypes & $\begin{array}{c}\text { Sl. } \\
\text { No }\end{array}$ & Genotypes & $\begin{array}{l}\text { Sl. } \\
\text { No }\end{array}$ & Genotypes \\
\hline $\mathbf{1}$ & Kagga & 21 & Kari mundaga & 41 & Ratan sagara & 61 & Rajamudi \\
\hline $\mathbf{2}$ & Mullu Bhatta & 22 & Kari dadi & 42 & Ratnachudi & 62 & Alur sanna \\
\hline $\mathbf{3}$ & Masuri Bhatta & 23 & Kempudooddi & 43 & Ratnagiri-24 & 63 & Chiman Sali \\
\hline $\mathbf{4}$ & BantwalaKempu Bhatta & 24 & Kerekallumutugya & 44 & MTU-1001 & 64 & Azucena \\
\hline $\mathbf{5}$ & Bile kalavi & 25 & Kirwana & 45 & Saratiga & 65 & GulwadiSannakki \\
\hline $\mathbf{6}$ & Champakali & 26 & Kyasari & 46 & Sarjan & 66 & Halaga Bhatta \\
\hline $\mathbf{7}$ & Dambersali & 27 & Farm valya & 47 & Selumsanna & 67 & KanadaTumba \\
\hline $\mathbf{8}$ & Doddamullare & 28 & Tanu & 48 & Waner-1 & 68 & Doddiga \\
\hline $\mathbf{9}$ & Murnavami Bhatta & 29 & Bidar local-1 & 49 & Wari Mysore sanna & 69 & NMS-2 \\
\hline $\mathbf{1 0}$ & Gandhasali & 30 & Mobane & 50 & Yadakmuki & 70 & Kara Bhatta \\
\hline $\mathbf{1 1}$ & Gopal Dodiga & 31 & Murukata Bhatta & 51 & Matta kara & 71 & Pokkali C \\
\hline $\mathbf{1 2}$ & Hegge & 32 & Mutalaga & 52 & Sannavalya & 72 & Ezhome 1 \\
\hline $\mathbf{1 3}$ & Holesalichipiga & 33 & Prassanna & 53 & ChittiMutyalu & 73 & Ezhome 2 \\
\hline $\mathbf{1 4}$ & Honasu & 34 & PusaSughandi & 54 & Jyothi & 74 & Hemavati \\
\hline $\mathbf{1 5}$ & Honnekattu & 35 & Pushpaka & 55 & Tanu & C1 & ARB-6 \\
\hline $\mathbf{1 6}$ & Chippiga & 36 & Putta batta & 56 & Bangarakovi & C2 & AM 143 \\
\hline $\mathbf{1 7}$ & HakkalaSali & 37 & Rajkamal & 57 & Bangaru sanna & C3 & Pokkali L \\
\hline $\mathbf{1 8}$ & Jigguvaratiga & 38 & Rajmani & 58 & Medisali & C4 & IR64 \\
\hline $\mathbf{1 9}$ & KagiSali & 39 & Rani & 59 & Ambemohar-2 & C5 & Chittimuthyalu \\
\hline $\mathbf{2 0}$ & Kari kantiga & 40 & Rasi & 60 & Mallige & & \\
\hline
\end{tabular}


Table.2 Analysis of variance (mean sum of squares) for 12 different characters in rice genotypes Aerobic condition $(\mathrm{n}=74)$

\begin{tabular}{|c|c|c|c|c|c|c|c|c|c|c|c|c|c|}
\hline \multirow[t]{2}{*}{ Source of variation } & \multirow[t]{2}{*}{ df } & \multicolumn{12}{|c|}{ Mean sum of square } \\
\hline & & PH & DFF & TNT & NPT & FLL & PL & TW & GL & GW & DGL & DGW & GY \\
\hline $\begin{array}{l}\text { Treatment (ignoring } \\
\text { Blocks) }\end{array}$ & 77 & $469 * * *$ & $75.73 *$ & $75.26 * * *$ & $59.9 * * *$ & $21.16^{* *}$ & $10.95 * * *$ & $31.68 * * *$ & $2.19 * * *$ & $0.20 * * *$ & $3.66 * * *$ & $0.13 * * *$ & $1.65 * * *$ \\
\hline Treatment: Check & 4 & $740 * * *$ & $129.19 * *$ & $227.84 * * *$ & $135.11 * * *$ & $58.20 * * *$ & $39.60 * * *$ & $180.83 * * *$ & $24.91 * * *$ & $0.79 * * *$ & $14.74 * * *$ & $0.60 * * *$ & $13.01 * * *$ \\
\hline Treatment: Test & 72 & $337 * * *$ & $560.48 * *$ & $67.66 * * *$ & $56.56 * * *$ & $17.32 *$ & $8.78 * * *$ & $23.72 * * *$ & $0.554 * *$ & $0.16 * * *$ & $2.28 * * *$ & $0.10 * * *$ & $0.98 * * *$ \\
\hline $\begin{array}{l}\text { Treatment: Test vs. } \\
\text { Check }\end{array}$ & 1 & $8901 * * *$ & $124.10 * *$ & $12.16 *$ & $0.13 *$ & $149.51 * * *$ & $52.87 * * *$ & $8.8 * * *$ & $29.72 * * *$ & $0.33 * *$ & $59.13 * * *$ & 0.04 & $4.56 * * *$ \\
\hline $\begin{array}{l}\text { Block (eliminating } \\
\text { Treatments) }\end{array}$ & 9 & 9 & 6.34 & 23.70 & 22.87 & 12.85 & $4.57 *$ & 0.11 & 0.33 & 0.067 & 0.22 & 0.02 & $0.73^{*}$ \\
\hline Residuals & 36 & 14 & 11.04 & 24.02 & 17.13 & 9.41 & 1.58 & 0.2 & 0.26 & 0.04 & 0.14 & 0.030 & 0.27 \\
\hline $\begin{array}{l}\text { Coefficient of } \\
\text { Variation }\end{array}$ & & 5.38 & 3.36 & 20.33 & 20.23 & 15.70 & 7.65 & 2.36 & 6.58 & 8.13 & 7.19 & 8.23 & 21.55 \\
\hline $\begin{array}{l}\text { Standard Error } \\
\text { difference }\end{array}$ & & 4.22 & 4.73 & 5.54 & 4.68 & 3.47 & 1.42 & 0.50 & 0.58 & 0.23 & 0.41 & 0.19 & 0.58 \\
\hline CD@ $5 \%$ & & 8.57 & 4.93 & 11.24 & 9.49 & 7.03 & 2.88 & 1.025 & 1.18 & 0.48 & 0.84 & 0.40 & 1.19 \\
\hline
\end{tabular}

*Significant at $5 \%$;* Significant at $1 \% * * *$ Significant at $0.1 \%$

DFF: Days to $50 \%$ flowering; PH: Plant height $(\mathrm{cm})$; TNT: Total number of tillers per plant; NPT: Number of productive tillers per plant; FLL: Flag leaf length, GY: Grain yield per plant (g); TW: test weight (g); GL: Grain length (mm); GW: Grain width (mm); DGL; Decorticated grain length (mm); DGL; Decorticated grain width (mm) 
Table.3 GCV, PCV and other genetic parameters of all the genotypes used for the study under Aerobic Condition ( $\mathrm{n}=74)$

\begin{tabular}{|c|c|c|c|c|c|c|c|c|c|c|c|c|}
\hline Aerobic & PH & DFF & TNT & NPT & FLL & PL & TW & GL & GW & DGL & DGW & Yld \\
\hline Mean & 75.36 & 98.92 & 23.88 & 20.24 & 20.25 & 16.92 & 18.73 & 7.54 & 2.54 & 4.66 & 2.15 & 2.55 \\
\hline Std Error & 2.08 & 19.97 & 0.97 & 0.89 & 0.48 & 0.32 & 0.55 & 0.10 & 0.05 & 0.17 & 0.04 & 0.12 \\
\hline Std Deviation & 18.33 & 40.58 & 8.58 & 7.82 & 4.21 & 2.86 & 4.85 & 0.87 & 0.42 & 1.54 & 0.33 & 1.04 \\
\hline Min & 43.32 & 82 & 7.29 & 5.63 & 12.45 & 9.34 & 9.59 & 5.80 & 1.51 & 1.54 & 1.43 & 0.11 \\
\hline Max & 133.65 & 119 & 36.82 & 31.23 & 33.43 & 25.01 & 28.66 & 11.10 & 3.32 & 8.08 & 2.72 & 5.01 \\
\hline PV & 337.13 & 382.78 & 67.66 & 56.56 & 17.32 & 8.78 & 23.72 & 0.55 & 0.17 & 2.28 & 0.10 & 0.98 \\
\hline GV & 323.18 & 361.22 & 43.64 & 39.43 & 7.91 & 7.20 & 23.52 & 0.29 & 0.13 & 2.14 & 0.07 & 0.71 \\
\hline $\mathbf{E V}$ & 13.96 & 24.57 & 24.02 & 17.13 & 9.41 & 1.58 & 0.20 & 0.27 & 0.04 & 0.14 & 0.03 & 0.27 \\
\hline GCV & 23.86 & 11.18 & 27.66 & 31.02 & 13.89 & 15.86 & 25.89 & 7.09 & 13.94 & 31.42 & 12.69 & 32.97 \\
\hline PCV & 24.37 & 11.67 & 34.45 & 37.16 & 20.56 & 17.52 & 26.00 & 9.87 & 16.21 & 32.40 & 15.10 & 38.77 \\
\hline ECV & 4.96 & 6.79 & 20.52 & 20.45 & 15.15 & 7.44 & 2.39 & 6.87 & 8.27 & 7.94 & 8.18 & 20.41 \\
\hline$h^{2}$ & 95.86 & 91.72 & 64.50 & 69.71 & 45.68 & 81.97 & 99.16 & 51.58 & 73.98 & 94.00 & 70.64 & 72.28 \\
\hline GA & 36.31 & 12.43 & 10.95 & 10.82 & 3.92 & 5.01 & 9.96 & 0.79 & 0.63 & 2.93 & 0.47 & 1.48 \\
\hline GAM & 48.18 & 22.05 & 45.84 & 53.44 & 19.37 & 29.62 & 53.18 & 10.51 & 24.74 & 62.83 & 22.01 & 57.82 \\
\hline Skewness (p.value) & 0.083 & 0.080 & 0.000 & 0.000 & 0.042 & 0.702 & 0.15 & 0.0008 & 0.007 & 0.012 & 0.063 & 0.742 \\
\hline Kurtosis (p.value) & 0.863 & 0.009 & 0.001 & 0.001 & 0.653 & 0.210 & 0.026 & 0.003 & 0.854 & 0.386 & 0.146 & 0.750 \\
\hline
\end{tabular}

PCV: Phenotypic coefficient of variance; GCV: Genotypic coefficient of variance; $h^{2}:$ Broad sense heritability; GAM: Genetic advance as percent of mean DFF: Days to $50 \%$ flowering; PH: Plant height (cm); TNT: Total number of tillers per plant; NPT: Number of productive tillers per plant; FLL: Flag leaf length, GY: Grain yield per plant (g); TW: test weight (g); GL: Grain length (mm); GW: Grain width (mm); DGL; Decorticated grain length(mm); DGL; Decorticated grain width (mm) 
Table.4 Estimates of phenotypic correlations coefficients for different quantitative traits in rice genotypes under aerobic condition $(n=74)$

\begin{tabular}{|c|c|c|c|c|c|c|c|c|c|c|c|}
\hline & DFF & PH & TNT & NPT & FLL & PL & GY & TW & GL & GW & DGL \\
\hline PH & -0.168 & 1 & & & & & & & & & \\
\hline TNT & 0.181 & $-0.290 *$ & 1 & & & & & & & & \\
\hline NPT & 0.237 & $-0.258 *$ & $0.906 * *$ & 1 & & & & & & & \\
\hline FLL & $0.551 * *$ & -0.402 & $0.301 *$ & $0.265^{*}$ & 1 & & & & & & \\
\hline PL & -0.037 & 0.077 & $-0.233 * *$ & $-0.240 * *$ & -0.025 & 1 & & & & & \\
\hline GY & -0.295 & $0.379 * *$ & -0.105 & -0.022 & -0.273 & 0.047 & 1 & & & & \\
\hline TW & -0.015 & 0.032 & -0.024 & -0.025 & 0.05 & 0.047 & $0.226 * *$ & 1 & & & \\
\hline GL & 0.048 & -0.172 & 0.15 & 0.222 & 0.045 & 0.17 & 0.135 & 0.096 & 1 & & \\
\hline GW & $-0.272 *$ & 0.224 & -0.13 & -0.076 & $-0.419 * *$ & 0.096 & $0.421 * *$ & $0.165^{*}$ & $0.378 * *$ & 1 & \\
\hline DGL & $-0.281 *$ & $0.338 * *$ & -0.233 & -0.179 & $-0.379 * *$ & 0.049 & $0.433 * *$ & $0.286 * *$ & $0.643 * *$ & -0.155 & 1 \\
\hline DGW & 0.23 & $-0.350 * *$ & 0.232 & $0.247 *$ & $0.291^{*}$ & 0.066 & -0.208 & $0.238 * *$ & -0.181 & $0.745 * *$ & $-0.763 * *$ \\
\hline
\end{tabular}

* Significant at $5 \%, * *$ significant at $1 \%$

DFF: Days to 50 \% flowering; PH: Plant height (cm); TNT: Total number of tillers per plant; NPT: Number of productive tillers per plant; FLL: Flag leaf length, GY:

Grain yield per plant (g); TW: test weight (g); GL: Grain length (mm); GW: Grain width (mm); DGL; Decorticated grain length (mm); DGL; Decorticated grain width (mm) 
Fig.1 Genotypic (GCV) and phenotypic co-efficient of variation (PCV) for different traits in rice genotypes under aerobic condition $(n=74)$

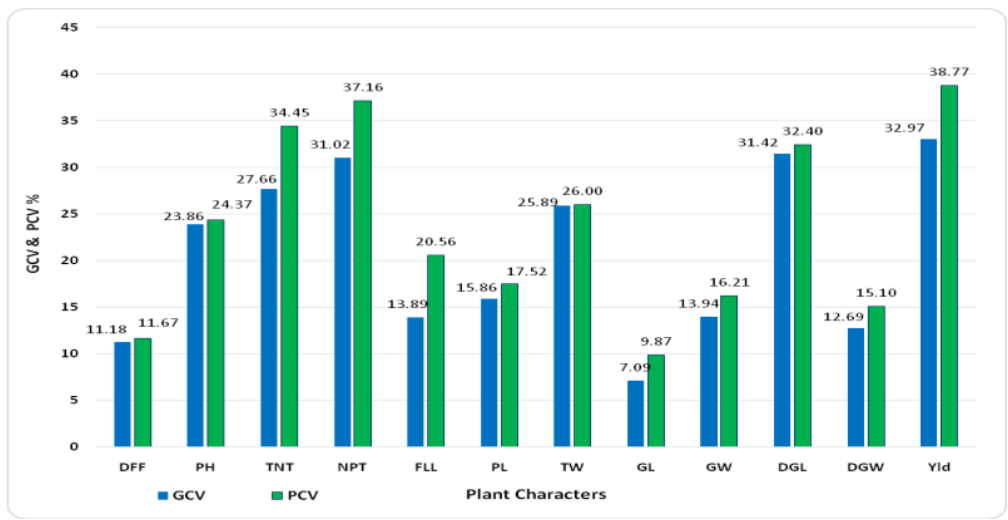

Fig.2 Heritability Broad Sense (hBS) and genetic advance as \% mean (GAM) for different traits in rice genotypes under aerobic condition $(n=74)$

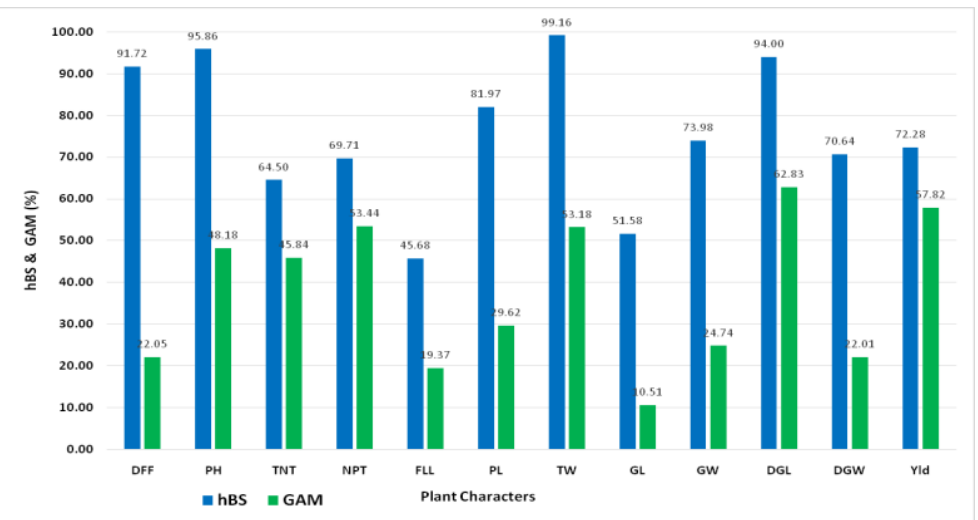

Narrow differences in PCV and GCV was recorded for test weight, days to fifty percent flowering, plant height, grain yield, plant height, panicle length, decorticated grain length \& width, number of tillers, number of productive tillers, grain length, grain width (Figure 1) suggested the presence of negligible influence of external factors for these traits.

While, genotypic co-efficient of variation indicates the amount of genetic variability present in the character, the heritability estimates aid in determining the relative amount of heritable portion of variation. Heritability estimates in broad sense would be reliable when accompanied by high genetic advance (Burton and Dewane, 1953). The broad sense heritability is the relative magnitude of genotypic to phenotypic variances for the traits and it is used as a predictive role in selection procedures.

Heritability in broad sense and GAM was high for all the characters studied except flag leaf length (45.68\%) and grain length $(51.58 \%)$. High heritability (> $70 \%$ ) was shown by grain yield per plant, days to first flowering, test weight, plant height, panicle length, test weight, grain width, decorticated grain length and width. These results were consistent with findings of Bastia et al., (2008) and Zhang et al., (2005) for 100 grains weight, grain width, Akinwale et al., (2011) 
for days to $50 \%$ flowering, plant height, 100 grains weight and yield per plant and ElMalky et al., (2008) for number of tillers per plant, test weight in rice.

High heritability coupled with high GAM was recorded for plant height, days to fifty percent flowering, total number of tillers per plant, number of productive tillers per plant, panicle length, grain yield per plant, test weight, grain width, decorticated grain length and decorticated grain width. Similar results were observed by Kumar et al., (2001) for plant height; Akinwale et al., (2011) for grain yield per plant; Bekele et al., (2013)for total number of tillers per plant, Sharma et al., (2004); Manjunath et al., (2012); Shet et al., (2012); Kiran et al., (2013); Sadimantara et al., (2014) for productive tillers per plant in rice.

High heritability coupled with moderate GAM was recorded for flag leaf length and grain length. However, Bidhan et al., (2001) reported for high heritability coupled with high genetic advance as percent mean for grain length.

These heritability and GAM from the study (Figure 2) indicated that, these characters were not much influenced by environmental factors. So, these traits were mostly controlled by additive and /or additive $x$ additive gene interactions and may respond to direct selection for trait improvement

\section{Correlation studies}

The study of relationship of different traits has great importance in the indirect selection of a complex trait associated with a simple trait. The correlation helps in identifying the possibility of improving yield through indirect selection of its component traits which are highly correlated. The results obtained for phenotypic correlations from the present study are presented in the Table 4 are discussed below.

Days to fifty percent flowering manifested significant positive correlation with flag leaf length (0.551) and number of productive tillers. Plant height exhibited a significant negative correlation with numbers of tillers (0.290) and number of productive tillers (0.258) and positive correlation with the panicle length and grain yield. Total number of tillers per plant has shown significant positive correlation with number of productive tillers per plant (0.906) Laxuman et al., 2011 also reported similar results.

Grain length is positively significantly correlating with the grain width. Grain width is negatively correlated with days to fifty percent flowering and flag leaf length. But positively correlated with grain yield, test weight and grain length. Decorticated grain length and width are significantly positively correlating with each other.

Grain yield per plant showed negative correlation with days to fifty percent flowering. Nagesh et al., (2012) reported similar results for days to days to $50 \%$ flowering and grain yield. Highly significant and positive correlation was observed for grain yield per plant with plant height, number of productive tillers per plant and number of tillers per plant. This result was in conformity with the reports by Raju et al., (2004), Shashidhar et al., (2005) and Nagesh et al., (2012). Grain yield also showed significant positive correlation with test weight, grain width and decorticated grain length.

In conclusion all selected 74 germplasm lines showed significant variation for the yield and its related traits under aerobic condition. The estimates of genetic variability parameters in the landraces indicated that there is a presence 
of narrow difference between PCV and GCV for all the studied traits indicating the least influence of environment in expression of these traits. Correlation analysis revealed most traits except days to fifty per cent flowering manifested significant positive correlation with grain yield which suggest simultaneous improvement of these traits is possible. Overall, the present field experiment revealed high heritability coupled with high genetic advance as per cent of mean for most of the characters indicating the presence of considerable variation and additive gene effects Hence, improvement of these characters could be effective through phenotypic selection.

\section{References}

Akinwale, M. G., Gregorio, G., Nwilene, F., Akinyele, B. O., Ogunbayo, S. A. and Odiyi, A. C., 2011, Heritability and correlation coefficient analysis for yield and its components in rice (Oryza sativa L.). African J. Pl. Sci., 5(3):207212.

Alam, M. Z., Bhuiya, M. A., Muttalib, M. A. and Rashid, M. M., 2004, Effect of alternating saline and non-saline conditions on emergence and seedling growth of rice. Pakistan J. Biol. Sci., 7:883-890.

Bastia D., Mishra T. K. and Das S. R. 2008. Genetic variability and selection indices for grain yield in upland rice. Oryza., 45 (1):72-75.

Bekele, B. D., Rakhi, S., Naveen, G. K., Kundur, P. J. and Shashidhar, H. E., 2013, Estimation of genetic variability and correlation studies for grain $\mathrm{Zn}$ concentrations and yield related traits in selected rice (Oryza sativa L.) genotypes. Asian J. Exp. Biol. Sci., 4 (3): $345-351$

Bidhan, R., Hossain, M., Hossain, F. and Roy, A., 2001, Genetic variability in yield components of rice (Oryza sativa L.). Envt. Ecol., 19: 186 - 189.

Bisne, R., Sarawgi, A. K. and Verulkar, S. B., 2009, Study of heritability, genetic advance and variability for yield contributing characters in rice. Ban. J. Agric. Res., 34 (2): 175 - 179.

Burton, G. M. and Dewane, E. M., 1953, Estimating heritability in tall Fescue (Festuca arandanaceae) from replicated clonal material. Agron.J., 45: $478-481$.

Elayaraja, K., Prakash, M., Saravanan, K.,Kumar, S. B. and Ganesan, J., 2005, Studies on variability, heritability and genetic advance for certain quantitative characters in mutant population of rice. Crop Res., 29: 134 - 137.

El-Malky, M., El-Habashy, M. and Abdelkhalik, A. F., 2008, Rice germplasm evaluation for agronomic traits and their influence on stem borer (Chilo Agamemnon Bles.) resistance. J. Agric. Res., 46 (3): 206 - 212.

Hanson, C. H., Robinson, H. F., and Comstock, R. E., 1956, Biometrical studies of yield in segregating population of Korean Lespedeza. Agron. J., 48: 267 - 282.

Kiani, G. and Nematzadeh, G., 2012, Correlation and path coefficient studies in $\mathrm{F}_{2}$ populations of rice. Not. Sci. Biol., 4 (2): 124 - 127.

Kiran, K. K., Rao, G, R. M. and Suresh, K., 2013, Variability and frequency distribution studies in $\mathrm{F}_{2}$ population of two crosses of rice (Oryza sativa L.). Asian J. Bio. Sci., 8 (2): 153 - 159.

Kumar, B., Thakur, R., Mishra, S. B. and Singh, D. N., 2001, Variability studies in segregating population of rice (Oryza sativa L.). Ann. Biol., 17(1): 43 - 45.

Laxuman, Salimath, P. M., Shashidhar, H. E., Mohankumar, H. D., PatiL, S. S., Vamadevaiahh, M. and JANAGOUDAR, B. S., 2011, 
Character association and path coefficient analysis among the backcross inbredlines derived from Indica X Nericacross for productivity traits in rice (Oryza sativa L.). Karnataka J. Agric. Sci., 24 (5): 626 628.

Manjunath, S. R., Rajanna, M. P., Ramesh, S., Sheshshayee, M. S. and Mahadevu, P., 2012, Genetic variability, correlation and path coefficient studies in $\mathrm{F}_{2}$ generation of aerobic rice (Oryza sativa L.). Elect. J. Plant. Breed., 3 (3): 925 931.

Nagesh, R, V., Usharani, G. and Dayakar, T., 2012, Grain iron and zinc association studies in rice (Oryza sativa L.) $\mathrm{F}_{1}$ progenies. Arch. App. Sci.Res., 4(1):696-702.

Raju, C. H. S., Rao, M. V. B. and Sudarshanam, A., 2004, Genetic analysis and character association in $\mathrm{F}_{2}$ generation of rice. Madras Agric. J., 91: $66-69$.

Ray, P. S. and Islam, M. A., 2008. Genetic analysis of salinity tolerance in rice. Bangladesh J. Agril. Res., 33(4): 519-529.

Roy, S. J., Tucker, E. J. and Tester, M., 2011, Genetic analysis of abiotic stress tolerance in crops. Curr. Opin. Pl. Biol., 14:232-239.

Sadimantara, G. R., Muhidin and Cahyono, E., 2014, Genetic analysis on some agro-morphological characters of hybrid progenies from cultivated paddy rice and local upland rice. Adv. Stud.
Biol., 6 (1): 7 - 18.

Sharma, G., Ravindra, S. G. and Roy, C., 2004, Genetic variability and heritability for 10 metric traits in upland rice varieties. Oryza, 39: 42 - 46.

Shashidhar, H. E., Pasha, F., Janamatti, M., Vinod, M. S. and KanbaR, A., 2005, Correlation and path co-efficient analysis in traditional cultivars and double haploid lines of rainfed lowland rice. Oryza, 42: 156 - 159.

Shashidhar, H. E., 2007, Aerobic rice: An Efficient Water Management Strategy for Rice Production. Food and water security in developing countries. Chapter 12. pp. $131-139$

Shashidhara, N., Biradar, H. and Hittalmani, S., 2013, genetic variation in $F_{3}$ and $F_{4}$ population of rice (Oryza sativa $\mathrm{L}$.) for grain protein content (GPC), seed nutrients, yield attributing parameters and parental polymorphisms. Bioinfolet, 10 (2): 572 - 580.

Shet, M. R., Rajanna, M. P., Ramesh, S., Sheshshayee, M. S. and Mahadevu, P., 2012, Genetic variability, correlation and path coefficient studies in $\mathrm{F}_{2}$ generation of aerobic rice (Orzya sativa L.). Elect. J. Plant Breed., 3 (3): 925 931.

Zhang, M. W., Guo, B. J. and Peng Z. M., 2005, Genetic effects on grain characteristics of indica black rice and their uses on indirect selections for some mineral element contents in grains. Genetic Resources and Crop Evolution, 52: 1121 - 1128.

\section{How to cite this article:}

Sowjanya, M. S., H. V. Vijayakumar Swamy, H. E. Shashidhar, Prakash Patil and Vimarsh, H. S. 2021. Genetic Variability Study of Rice Germplasm Accessions under Aerobic Condition. Int.J.Curr.Microbiol.App.Sci. 10(01): 452-463. doi: https://doi.org/10.20546/ijcmas.2021.1001.056 